\title{
THE ISOLATION OF SUB-SAHARAN FLOATING CURRENCIES
}

\author{
[Izolace subsaharských plovoucích měnových kurzů] \\ Gábor Dávid Kiss ${ }^{1}$, Julianna Pontet ${ }^{2}$ \\ ${ }^{1}$ University of Szeged, Faculty of Economics and Business Administration, Kálvária sgt. 1, 6722 Szeged, \\ Hungary \\ Email:kiss.gabor.david@eco.u-szeged.hu \\ ${ }^{2}$ University of Szeged, Faculty of Economics and Business Administration, Kálvária sgt. 1, 6722 Szeged, \\ Hungary \\ Email: pontet.julianna@gmail.com
}

\begin{abstract}
The paper tested contagion effects among free floating African currencies and Euro with a control variable like the Euro-pegged CFA Franc. Contagion should be based on deep trade, funding and political relationships which was valid for connections between African countries and such developed countries like the United States or the Eurozone. The theory suggests increased common movements under shock periods which were tested on a daily time series between 2000 and 2015, studying relationships under recession periods in the United States or the Eurozone or under days with extreme fluctuation. The results presented contagions only for the emerging South African currency while the others proved to be relatively independent.
\end{abstract}

Keywords: Africa, contagion, extreme fluctuation, floating regime.

JEL classification: C32, F31, F35

Doručeno redakci: 14.10.2015; Recenzováno: 26.10.2015; 28.10.2015; Schváleno k publikování: 23.3.2016

\section{Introduction}

Current paper evaluates the consequences of floating on Sub-Saharan African currencies to see the possible trade-offs between price-competitiveness and foreign exchange (FX) exposure. Peg is a political commitment to eliminate FX exposure with a perfect comovement between pegged and amplitude of extreme fluctuation is limited. However, pricecompetitiveness can be biased by appreciating trends of the selected key currency - while the maintenance can be expensive under turbulent times as well. Floating regime has the advantage of adaption in our current two-key-currency world, but later defined contagions and divergences can ruin the profitability due to unexpected change in currency common movements. The operative objective of this paper is to check upper hypotheses about currency regimes on the selected country set: occurrence of extreme currency fluctuations should be limited under peg, they should be isolated from volatility spillover and shall maintain a strong correlation with Euro (IMF 2013). Floating regimes should present the well-known properties increased extreme fluctuation under crisis periods, some sort of volatility spillover with neighbouring countries and other key trade partners as well as the strength of the comovement with Euro should be the subject of market conditions. These results can be important to calibrate international and national aid and development programs.

After the definition of contagion and its background are discussed, special African tradeprograms will be summarized in the theoretical chapter. Current study tested daily closing data of floating currencies from Kenya (KES), Ghana (GHS), South Africa (ZAR), Tanzania (TZS), Uganda (UGX), Gambia (GMD), Madagascar (MGA) and Mozambique (MZN) in USD denomination against EUR/USD rate between March 82000 and March 62015 acquired from Bloomberg database. These currencies have poor literature despite the enormous international efforts to stabilize these countries external imbalances. The selected time period 
covers three crisis periods (dot-com, subprime and PIGS), allowing us to capture currency misbehaviours under extreme circumstances. The basic statistics and the ways to analyse their extreme fluctuation, volatility and correlation are the content of the data and methods chapter. Results are supporting the advantages of floating regime, which was remarkably isolated from key currency developments.

\section{Theoretical Background}

This chapter defines contagion channels to study vulnerability of sample countries. Floating exchange rate regime was applied in the selected countries, while their external balance is in focus of the presented international initiatives in the following paragraphs.

Contagions could be broadly defined as the cross-country transmission of shocks or the general cross-country spillover effects, which does not need to be related to crises. Current paper applies the World Bank's very restrictive definition ${ }^{1}$ : a relative increase ${ }^{2}$ in crosscountry correlations during "crisis times" to "tranquil times" - when a shock to one or a group of markets, countries, or institutions, spread to other markets, or countries, or institutions (Pritsker, 2001). Contagion is based on three fundamental links among countries, like financial, real and political links. Financial link is supported by connections through the international financial system (common financial institutions, interconnected lenders, nonbank financial market participants). Real links are in connection with international trade or FDI-driven cross-border division of labour. Political link is in connection with exchange rate arrangement country-groups as well as other current transfers or debt forgiveness due to international cooperation. Contagion transmission channels can be paired with specific balance of payments components which will be used during further evaluations of Africandeveloped-emerging relationships.

The analyzed African country set followed free floating exchange rate mechanism combined with monetary aggregate target in the majority of the cases (Kenya, Tanzania, Uganda, Gambia, Madagascar, Mozambique) or inflation targeting framework (Ghana, South Africa) (IMF, 2013). Main trading partners were the European Union, United States, China and India in 2012 (CIA, 2015). Foreign trade was supported via a rich and chaotic net of regional integration agreements fostering trade of goods and services among selected countries and key economic areas (EU, US, Indian and Chinese markets) (Udvari 2012). Aid for Trade (AfT) initiative was created after the G8 Summit in 2005 to improve supply-side capacities of recipient countries instead of former "trade not aid" philosophy. The objective of this program was to integrate the recipient countries in the world economy, to diversify their foreign trade and to maintain their price-competitiveness under the current environment with decreasing tariffs - where former Generalized System of Preferences (GSP) became obsolete (Udvari, 2011). The European Union has been focusing most of its international aid-activity on African countries since the first Lome Agreement in 1975 even in the current Cotonou Agreement between 2000 and 2020 trough its financial (European Development Fund, dedicated EIB credits, economic stability aid programs) and trade instruments (GSP, unilateral preferences, WTO agreements and European Partnership Agreements) (Udvari, 2008, 2011, 2012). The U.S. also offers incentives for Sub-Saharan countries to open their economies and build free markets. The African Growth and Opportunity Act (AGOA) was approved by the U.S government in 2000. AGOA is a nonreciprocal trade preference program that provides dutyfree treatment to U.S. imports of certain products from actually 39 SSA countries; the Act is similar to the GSP but includes trade and development provisions beyond duty-free

\footnotetext{
${ }^{1}$ see: http://go.worldbank.org/JIBDRK3YC0

${ }^{2}$ We can talk about interdependence, when the upper difference between correlations under extreme and normal conditions is insignificant - meaning that upper links have no significant impact on exchange rates.
} 
preferences (Williams, 2015). Project financing was a traditional field of World Bank Group, especially International Development Association (IDA) to provide interest-free loans for governments of Heavily Indebted Poor Countries (HIPC). Funding for corporate sector has a bigger variety: among another WB subsidiaries and regional development banks, the ChinaAfrica Development Fund was established in 2007 to finance development projects on commercial basis for corporate sector, supported by China Development Bank (CADF, 2013). Thanks to South-South economic engagements, in recent years India and China as emerging economies have also become the main trade partners for African economies in a range of products (Dash, 2014). Upper programs are common in their political influence on target countries current and financial accounts, enriching the range of contagion possibilities (Fig. $1)$.

Figure 1: Contagion Channels and Balance of Payments

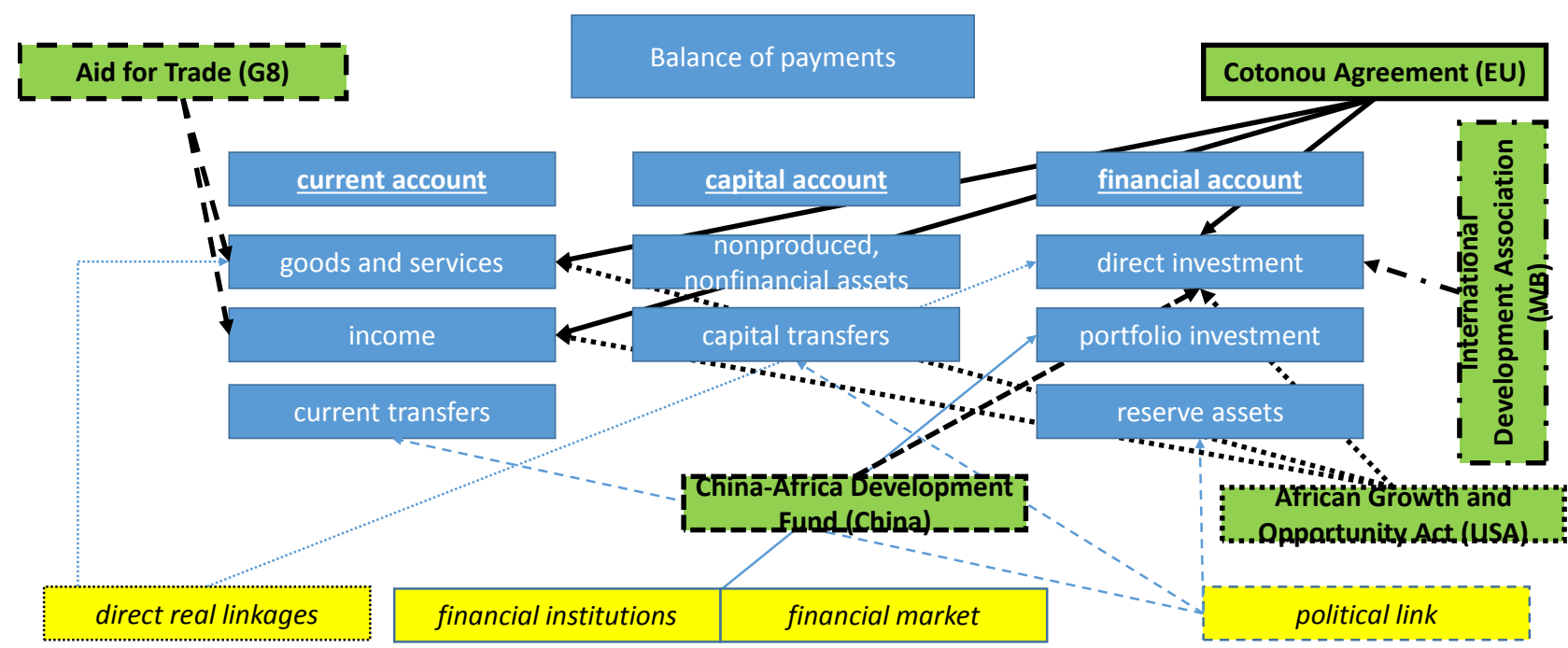

Contagion channels

Source: IMF (2009), Pritsker (2001)

However, it can be misleading to treat Sub-Saharan Africa as a club due to the enormous intra and inter-regional deviations, causing lack of convergence among them (Mccoskey, 2002). Despite the upper presented wide range of support channels, Lomé and Cotonou Agreements had no significant impact on sigma (income deviations), beta (less developed has bigger growth-potential) and stochastic (entire country-group develops among a common trend) convergence (Gáspár and Udvari, 2011) or trade with European countries (Udvari, 2014). GDP per capita growth in Africa was increased in the past mostly by enhancements in literacy, investment, FDI and urban agglomeration via strengthening human and physical capital (Naudé, 2004). These results can make political and real linkages as primary contagion channels - because all of the political initiatives were made to compensate insufficient financial conditions. Can we increase the resilience of African countries with weak and policy-driven financial links? Past crisis experience supports this idea: South African stock exchange and bond markets suggested a marginal depreciation during the Asian crisis (Siriwardana and Dollery, 2002), but under global risk aversion periods a wide range of 
developed and emerging currencies (like South African Rand) tended to depreciate (De Bock and de Carvalho Filho, 2015). Size, liquidity and access are influencing factors of foreign investor participation to integrate a market into global capital flows - Collins and Biekpe (2003) suggest that as a reason why only stock markets in South Africa, Egypt, Namibia and Morocco presented contagion under Asian crisis. This idea is supported by Morales and Andreosso-O'Callaghan (2014) who suggest that financial crisis impact related to market integration level.

Current paper cites Visegrad group ${ }^{3}$-related experience to focus expectations. This country-set has been the subject of numerous articles to study their affections for contagions - while they are also the subject of policy-related transfers and their FDI, trade and banking relations are dominated by Eurozone-located factors but the overall size of their banking system or capital market is marginal (Farkas, 2011, Heryán, 2015). These relations had significant impact on strong common movement among currencies (Stavárek, 2010, Babetskaia-Kukharchuk et al., 2008, Bubák et al., 2011, Kiss and Schuszter, 2015), biased by crisis-related developments. Obviously these countries are closer to the developed than to the emerging status, while only South Africa is recognized as an emerging market from our African country-set according to their BRICS membership ${ }^{4}$. However, it can underline some significant differences among poor and emerging currencies - like the tightness of their common movements, volatility spillovers and extreme fluctuations.

Foreign exchange (FX) exposure can have a crucial impact on the competitiveness of analyzed African countries due to their floating currency regime framework. Combined with high dependence on euro and US dollar denominated markets (China is considered here, because of the $2 \%$ floating band of RMB against US dollar ${ }^{5}$ ) and diverse financial and trade support channels, contagion on currency market is a real option. This is the opposite strategy than that followed by member states ${ }^{6}$ of West African Economic and Monetary Union ${ }^{7}$, where CFA franc has a fixed parity to the Euro (656 to 1).

\section{Data and Methods}

Methods to capture temporal distribution of extreme FX fluctuations and contagions under recession periods in developed markets are presented in this chapter. The literature of African currencies is really narrow: only South African Rand was studied by De Bock et al. (2015) or Keskina et al. (2011) while Collins and Biekpe (2003) or Siriwardana and Dollery (2002) studied a wider African subset of equity markets with a result of isolation.

\footnotetext{
${ }^{3}$ Czech Republic, Hungary, Poland, Slovakia

${ }^{4}$ South African Rand, Brazil Real and Turkish Lira tended to be part of the same cluster in the past (Keskina et al. 2011).

${ }^{5}$ http://www.pbc.gov.cn/publish/english/955/2014/20140317160839706274217/20140317160839706274217_.ht $\mathrm{ml}$

${ }^{6}$ Benin, Burkina-Faso, Côte d'Ivoire, Mali, Niger, Senegal, Togo, and Guinea-Bissau

${ }^{7}$ http://go.worldbank.org/FKHEP1VQF0
} 
Figure 2: Developments of Selected African Currencies between 2000 and 2015 (March 8 $2000=100 \%$ )

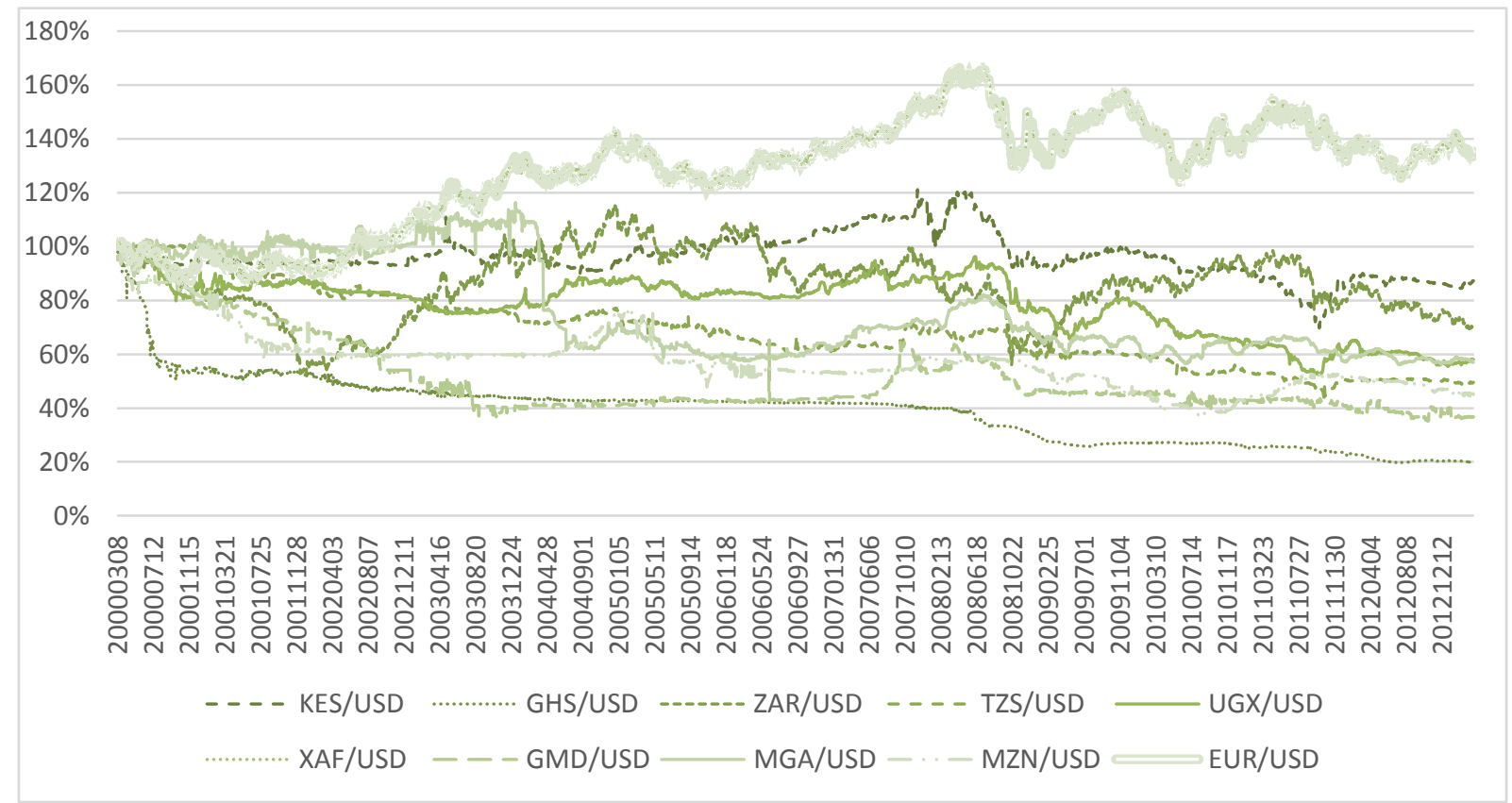

Source: Bloomberg

CFA Franc (XAF) followed strictly the euro, due to its fixed regime, showing an appreciation against US dollar during the entire time set on Fig. 2. Kenyan Shilling (KES) and South African Rand (ZAR) presented an appreciating trend before the crisis only, otherwise all off the entire currency set depreciated against the US dollar - price-competitiveness improved from this aspect.

Table 1: Descriptive Statistics of Currency Logarithmic Differentials

\begin{tabular}{|c|c|c|c|c|c|c|c|}
\hline \multirow[b]{2}{*}{ currency } & \multirow[b]{2}{*}{ mean } & \multirow[b]{2}{*}{ skewness } & \multirow[b]{2}{*}{ kurtosis } & \multicolumn{2}{|c|}{ normal distribution autocorrelation } & \multirow{2}{*}{\begin{tabular}{|l} 
heteroscedasticity \\
ARCH-LM (p)
\end{tabular}} & \multirow{2}{*}{\begin{tabular}{|l|} 
stationarity \\
ADF (p)
\end{tabular}} \\
\hline & & & & Jarque-Bera $(\mathrm{p})$ & Ljung-Box (p) & & \\
\hline KES/USD & \begin{tabular}{|l|l|}
0,00 & 0,01 \\
\end{tabular} & 0,32 & 20,62 & $0,00^{*}$ & $0,00 * *$ & 0,22 & 0,00 \\
\hline GHS/USD & \begin{tabular}{ll|l|}
0,00 & 0,01 \\
\end{tabular} & 1,25 & 34,58 & $0,00 *$ & $0,00 * *$ & $0,00 * * *$ & 0,00 \\
\hline ZAR/USD & \begin{tabular}{|l|l|l|}
0,00 & 0,01 \\
\end{tabular} & 1,05 & 15,75 & $0,00 *$ & $0,01 * *$ & 0,14 & 0,00 \\
\hline TZS/USD & \begin{tabular}{l|l|l|}
0,00 & 0,01 \\
\end{tabular} & $-0,83$ & 40,58 & $0,00 *$ & $0,00 * *$ & $0,00 * * *$ & 0,00 \\
\hline UGX/USD & \begin{tabular}{|l|l|l|}
0,00 & 0,01 \\
\end{tabular} & 0,47 & 17,08 & $0,00 *$ & $0,00 * *$ & $0,02 * * *$ & 0,00 \\
\hline XAF/USD & \begin{tabular}{ll|l|}
0,00 & 0,01 \\
\end{tabular} & $-0,13$ & 5,26 & $0,00 *$ & $0,00 * *$ & $0,00 * * *$ & 0,00 \\
\hline GMD/USD & \begin{tabular}{l|l|}
0,00 & 0,02 \\
\end{tabular} & $-0,05$ & 174,94 & $0,00 *$ & $0,00 * *$ & $0,03 * * *$ & 0,00 \\
\hline MGA/USD & \begin{tabular}{|l|l|l|}
0,00 & 0,01 \\
\end{tabular} & 1,73 & 59,42 & $0,00 *$ & $0,00 * *$ & $0,00 * * *$ & 0,00 \\
\hline MZN/USD & \begin{tabular}{l|l|}
0,00 & 0,01 \\
\end{tabular} & 0,81 & 43,05 & $0,00 *$ & $0,00 * *$ & $0,00 * * *$ & 0,00 \\
\hline EUR/USD & $0,00 \mid 0,01$ & $-0,02$ & 4,39 & $0,00 *$ & 0,51 & 0,59 & 0,00 \\
\hline
\end{tabular}

Notes: *: lack of normal distribution, **: autocorrelation at 2 lags, ***: heteroscedasticity at 2 lags, ****: unit root

Source: authors' calculations

Logarithmic differentials (1) of FX rates were tested to understand their basic characteristics on Tab. 1.

$r_{t}=\ln \left(\frac{p_{t}}{p_{t-1}}\right)$

Where $r_{t}$ represents logarithmic return on trade day $t$, and $p$ is FX rate. 
Currencies had enormous fifth moments (kurtosis) compared to the ideal level of 3, suggesting that large magnitude fluctuations are more probable that they should be under the assumption of normal distribution. After this result the rejection of normal distribution by Jarque-Bera test was not a surprise. Time series were auto correlated with 2 lag, falsifying the common assumption about weak market efficiency. The appearance of heteroscedasticity suggests the future application of Generalized Autoregression Heteroscedasticity (GARCH) models to avoid correlation bias following Forbes and Rigobon (2002). There was no unit root in the data by the ADF test.

Contagions were defined as significant increase in correlations due to some kind of shock (2)

$\rho_{\text {shock }} \gg \rho_{\text {tranqil }}$,

where $\rho_{\text {shock }}$ represents correlation under shock periods and $\rho_{\text {tranqil }}$ are correlations under "normal" periods. Current paper analyses two forms of shocks on the selected currency set i.e. a short-run and a long-run approach will be applied.

Short-run shocks were defined by non-normal distributed unconditional quantile of empirical data, referred as fat tailed extreme returns $\left(r_{\mathbb{X} f a t}\right)$ computed by the difference on the tails between theoretical normal and empirical distribution utilizing its "S"-shaped form, described by Clauset (2007) and Gabaix et al. (2003) to see the difference between theoretical and empirical returns under $p_{L}$ low probability (3).

$r_{\mathbb{X} f a t+, p_{L}} \gg r_{\text {normal, } p_{L}}$ or $r_{\mathbb{X} f a t-, p_{L}} \ll r_{\text {normal }, p_{L}}$ where $p_{L} \ll p_{E(r)}$

Fat tailed extreme returns can appear both on negative $\left(r_{\mathbb{X} f a t-, p_{L}}\right)$ and positive $\left(r_{\mathbb{X} f a t+, p_{L}}\right)$ side of probability distribution under $p_{L}$ low probable cases which are far from the probability of the expected value $\left(p_{E(r)}\right)$.

Long-run shocks were defined by business cycles in the US and Eurozone following NBER ${ }^{8}$ and CEPR Euro Area Business Cycle Dating Committee ${ }^{9}$ data. Recession was defined by both of them as "a significant decline in economic activity spread across the economy, lasting more than a few months, normally visible in real GDP, real income, employment, industrial production, and wholesale-retail sales". US recession periods were defined by this method between March and November 2001 as well as between December 2007 and June 2009. Eurozone was in recession between January 2008 and April 2009 (which was really close to the US recession period) and after July 2011 and has not ended yet.

Different GARCH models were fitted on the data to manage heteroscedasticity of underlying data before later correlation fitting, following Cappeiello, Engle and Sheppard (2006). The applied GARCH(p,q), GJR GARCH(p,o,q), TARCH(p,o,q) and $\operatorname{APARCH}(p, o, q)$ (4-8) models can be useful to capture volatility developments and their clustering in time (heteroscedasticity).

$\operatorname{GARCH}(\mathrm{p}, \mathrm{q}): \quad \sigma_{t}^{2}=\omega+\sum_{i=1}^{p} \alpha_{i} \varepsilon_{t-i}^{2}+\sum_{j=1}^{q} \beta_{i} \sigma_{t-j}^{2}$.

where $\sigma_{t}^{2}$ represents present variance, $\omega$ is a constant term, $p$ denotes the lag number of squared past $\varepsilon_{t-i}^{2}$ innovations with $\alpha_{i}$ parameters, while $q$ denotes the lag number of past $\sigma_{t-j}^{2}$.variances with $\beta_{i}$ parameters to represent volatility persistence. Asymmetric GARCH models can be introduced via

$\left\{\begin{array}{l}S_{t-i}^{-}=1, \text { if } \varepsilon_{t-i}<0 \\ S_{t-i}^{-}=0, \text { if } \varepsilon_{t-i} \geq 0\end{array}\right.$ as a sign asymmetric reaction to decreasing returns.

\footnotetext{
${ }^{8} \mathrm{http}: / / \mathrm{www}$. nber.org/cycles.html

${ }^{9} \mathrm{http}: / /$ www.cepr.org/content/euro-area-business-cycle-dating-committee
} 
$\operatorname{GJR} \operatorname{GARCH}(\mathrm{p}, \mathrm{o}, \mathrm{q}): \sigma_{t}=\omega+\sum_{i=1}^{p} \alpha_{i}\left|\varepsilon_{t-i}\right|+\sum_{i=1}^{o} \gamma_{i} S_{t-i}^{-}\left|\varepsilon_{t-i}\right|+\sum_{j=1}^{q} \beta_{i} \sigma_{t-j}$,

$\operatorname{TARCH}(\mathrm{p}, \mathrm{o}, \mathrm{q}): \quad \sigma_{t}^{2}=\omega+\sum_{i=1}^{p} \alpha_{i} \varepsilon_{t-i}^{2}+\sum_{i=1}^{o} \gamma_{i} S_{t-i}^{-} \varepsilon_{t-i}^{2}+\sum_{j=1}^{q} \beta_{i} \sigma_{t-j}^{2}$,

$\operatorname{APARCH}(\mathrm{p}, \mathrm{o}, \mathrm{q}): \quad \sigma_{t}^{\delta}=\omega+\sum_{i=1}^{p} \alpha_{i}\left(\left|\varepsilon_{t-i}\right|-\gamma_{i} \varepsilon_{t-i}\right)^{\delta}+\sum_{j=1}^{q} \beta_{j} \sigma_{t-j}^{\delta}$,

where $\alpha_{i}>0(i=1, \ldots, p), \gamma_{i}+\alpha_{i}>0(i=1, \ldots, o), \beta_{i} \geq 0(i=1, \ldots, q), \alpha_{i}+0,5 \gamma_{j}+\beta_{k}+<1(i=1, \ldots, p$, $j=1, \ldots, o, k=1, \ldots, q)$ and $\delta$ index parameter can be between 1 and 2 .

Model selection was made with focus on homoscedastic residuals (using a 2 lagged ARCHLM test), searching for the lowest Bayesian Information Criteria (BIC). This study applies DCC-GARCH ${ }^{10}$ model, following Engle (2002), to analyze the daily common movements of the selected markets.

Short-run volatility-spillovers on GARCH residuals were analyzed by Vector Autoregression (VAR) models, following Rejeb and Boughrara (2015). Our VAR captures the dynamic interactions for a set of $K$ vector of volatility series variables $h_{t}=\left(h_{1 t}, \ldots, h_{K t}\right)^{\prime}$. Substituting into the basic model of order p VAR has the form of (15) (Lütkepohl and Kratzig, 2004).

$h_{t}=A_{1} h_{t-1}+\cdots+A_{p} h_{t-p}+u_{t}$

Where the $A_{i}$ 's are $(K x K)$ coefficient matrices and $u_{t}=\left(u_{1 t}, \ldots, u_{K t}\right)^{\prime}$ is an unobservable error term - assumed to be a zero-mean independent white noise process with time-invariant, positive definite covariance matrix: $u_{t} \sim\left(0, E\left(u_{t}, u_{t}^{\prime}\right)\right)$. Our lag-selection focused on the lack of autocorrelation of $u_{t}$. Dynamic interactions among currency conditional volatilities (risk) depending on their own past values and other currencies tell many things about the interrelatedness of the selected currency.

The sample countries direct their foreign trade into the direction of US dollar (or USDpegged) and euro-denominated markets. A fixed exchange rate against euro endangers pricecompetitiveness under a period of euro-appreciation, while a floating regime is able to adapt. However, economic actors have to manage their FX exposure on both sides of their balance sheets, where a sudden change in currency common movement can undermine projectprofitability. For deeper understanding of the impact of shocks on common movements, contagion, divergence and interdependence were defined to capture all possible outcomes when we can find high levels of conditional correlations.

Contagion (10) occurs between euro, $c_{k}$ currencies when the $\rho^{\text {euro, } c_{k}}$ cross-market correlation becomes significantly higher due to a shock derived from EUR/USD market $\left(r_{x}^{\text {EUR/USD }}\right)$ spreading to the others or as a result of other external factors (Forbes and Rigobon, 2002, Campbell et al., 2002, Bekaert et al., 2005):

$r_{x}^{E U R / U S D}=1 \rightarrow \rho_{n}^{\text {euro, } c_{k}} \ll \rho_{x}^{\text {euro, } c_{k}}$,

Interdependence (11) occurs between euro, $c_{k}$ currencies when the $\rho^{\text {euro, } c_{k}}$ cross -market correlation is not significantly different, but the level of correlation is consistently high (Forbes and Rigobon,, 2002):

$r_{x}^{\text {EUR/USD }}=1 \rightarrow \rho_{n}^{\text {euro, } c_{k}} \approx \rho_{x}^{\text {euro, } c_{k}}$,

Divergence (12) occurs between euro, $c_{k}$ currencies when the $\rho^{\text {euro, } c_{k}}$ cross-market correlation becomes significantly lower due to a shock derived from one market $\left(r_{x}^{E U R / U S D}\right)$ spreading to others or as a result of other external factors (Bearce, 2002):

$r_{x}^{E U R / U S D}=1 \rightarrow \rho_{n}^{\text {euro, } c_{k}} \gg \rho_{x}^{\text {euro, } c_{k}}$,

\footnotetext{
${ }^{10}$ The estimation based on the Oxford MFE and UCSD toolboxs, developed by Kevin Sheppard: http://www.kevinsheppard.com/
} 
This chapter summarized the available information on the data and the applied methodology to test, how selected African currencies behaved under the market shocks.

\section{Results}

The lack of normal distribution at the logarithmic returns suggested a success on the detection of fat tailed extreme fluctuations. Tab. 2 contains the results of the method, suggesting that the remaining $r(n)$ truncated distribution converged closer to the ideal values of the first four moments: $\mathrm{N} \sim(0,1,0,3)$ - while the mean remained around zero, standard deviation was decreased (due to lack of excessive fluctuation), times series became less asymmetric (except GMD and EUR), while kurtosis is now closer to 3. At the same time, the applied method was able to manage the asymmetric appearance of extreme returns, while their overall mass remained lower than $10 \%$ in the entire data set.

Table 2: Fat Tailed Extreme Returns (Currencies in USD Denomination)

\begin{tabular}{|c|c|c|c|c|c|c|c|c|c|c|c|}
\hline \multicolumn{2}{|l|}{ currency } & KES & GHS & ZAR & TZS & UGX & XAF & GMD & MGA & MZN & EUR \\
\hline \multirow[b]{2}{*}{ mean } & entire & 0,00 & 0,00 & 0,00 & 0,00 & 0,00 & 0,00 & 0,00 & 0,00 & 0,00 & 0,00 \\
\hline & $\mathrm{r}(\mathrm{n})$ & 0,00 & 0,00 & 0,00 & 0,00 & 0,00 & 0,00 & 0,00 & 0,00 & 0,00 & 0,00 \\
\hline \multirow[b]{2}{*}{ standard deviation } & entire & 0,01 & 0,01 & 0,01 & 0,01 & 0,01 & 0,01 & 0,02 & 0,01 & 0,01 & 0,01 \\
\hline & $\mathrm{r}(\mathrm{n})$ & 0,00 & 0,01 & 0,01 & 0,00 & 0,00 & 0,00 & 0,01 & 0,01 & 0,01 & 0,00 \\
\hline \multirow[b]{2}{*}{ skewness } & entire & 0,32 & 1,25 & 1,05 & $-0,83$ & 0,47 & $-0,13$ & $-0,05$ & 1,73 & 0,81 & $-0,02$ \\
\hline & $\mathrm{r}(\mathrm{n})$ & $-0,08$ & 0,09 & $-0,08$ & 0,04 & $-0,02$ & $-0,07$ & $-0,07$ & 0,03 & $-0,08$ & $-0,05$ \\
\hline \multirow[b]{2}{*}{ kurtosis } & entire & 20,62 & 34,58 & 15,75 & 40,58 & 17,08 & 5,26 & 174,94 & 59,42 & 43,05 & 4,39 \\
\hline & $r(n)$ & 3,85 & 4,81 & 2,72 & 3,76 & 3,23 & 2,62 & 4,81 & 4,53 & 5,03 & 2,50 \\
\hline \multicolumn{2}{|c|}{$\mathrm{X}+$ treshold } & 0,01 & 0,02 & 0,02 & 0,01 & 0,01 & 0,01 & 0,04 & 0,03 & 0,03 & 0,01 \\
\hline \multicolumn{2}{|c|}{ X-treshold } & $-0,01$ & $-0,02$ & $-0,02$ & $-0,01$ & $-0,01$ & $-0,01$ & $-0,04$ & $-0,03$ & $-0,03$ & $-0,01$ \\
\hline \multicolumn{2}{|l|}{ Number of $\mathrm{X}+$} & 118 & 101 & 162 & 84 & 114 & 192 & 73 & 68 & 83 & 220 \\
\hline \multicolumn{2}{|c|}{ Number of X- } & 102 & 102 & 73 & 75 & 82 & 149 & 53 & 64 & 66 & 163 \\
\hline \multicolumn{2}{|c|}{ Number of $r(n)$} & 3693 & 3710 & 3678 & 3754 & 3717 & 3572 & 3787 & 3781 & 3764 & 3530 \\
\hline
\end{tabular}

Notes: X+ means extreme positive fat tailed extreme returns, while $X$ - means extreme negative fat tailed extreme returns. Usual or "normal" market days are represented by the $r(n)$ truncated distribution. Highlighted area: fixed exchange rate policy.

Source: authors' calculations

The temporal distribution (percentage of extreme re) of fat tailed extreme returns was tested in Tab. 3, to check the increase of their mass under recession. US recession benchmark seemed to be better to capture a slightly increase in the occurrence of extreme fluctuations. The accommodative monetary policy in the Eurozone following the July 2011 crisis had a relaxing impact on currency pricing (except Ghana, Tanzania and Madagascar).

Table 3: Fat Tailed Extreme Returns (Currencies in USD Denomination)

\begin{tabular}{|c|c|c|c|c|c|c|c|c|c|c|c|}
\hline period & KES & GHS: & ZAR & TZS & UGX & $\mathrm{XAF}$ & GMD & MGA & $\mathrm{MZN}$ & EUR & recession \\
\hline March 2000 - February 2001 & $1 \%$ & $20 \%$ & $7 \%$ & $2 \%$ & $2 \%$ & $6 \%$ & $2 \%$ & $4 \%$ & $0 \%$ & $6 \%$ & \\
\hline March 2001 - October 2001 & $9 \%$ & $13 \%$ & $10 \%$ & $1 \%$ & $1 \%$ & $13 \%$ & $26 \%$ & $15 \%$ & $3 \%$ & $12 \%$ & \\
\hline November 2001 - November 2007 & $9 \%$ & $1 \%$ & $9 \%$ & $6 \%$ & $5 \%$ & $10 \%$ & $2 \%$ & $2 \%$ & $4 \%$ & $10 \%$ & \\
\hline December 2007 - May 2009 & $4 \%$ & $\mathbf{0 \%}$ & $3 \%$ & $3 \%$ & $3 \%$ & $9 \%$ & $4 \%$ & $1 \%$ & $4 \%$ & $12 \%$ & $"+"$ \\
\hline US June 2009 - February 2015 & $4 \%$ & $5 \%$ & $4 \%$ & $3 \%$ & $3 \%$ & $5 \%$ & $3 \%$ & $2 \%$ & $1 \%$ & $7 \%$ & \\
\hline March 2000 - December 2007 & $8 \%$ & $4 \%$ & $8 \%$ & $5 \%$ & $4 \%$ & $10 \%$ & $4 \%$ & $4 \%$ & $3 \%$ & $10 \%$ & \\
\hline January 2008 - March 2009 & $4 \%$ & $0 \%$ & $2 \%$ & $4 \%$ & $3 \%$ & $11 \%$ & $5 \%$ & $1 \%$ & $4 \%$ & $14 \%$ & $"+"$ \\
\hline April 2009 - June 2011 & $7 \%$ & $0 \%$ & $6 \%$ & $2 \%$ & $5 \%$ & $6 \%$ & $3 \%$ & $0 \%$ & $0 \%$ & $9 \%$ & \\
\hline EU July 2011 - March 2015 & $\mathbf{0 \%}$ & $11 \%$ & $1 \%$ & $4 \%$ & $1 \%$ & $2 \%$ & $3 \%$ & $4 \%$ & $1 \%$ & $4 \%$ & $"+"$ \\
\hline
\end{tabular}

Source: authors' calculations 
Heteroscedasticity of time series were managed by different GARCH models, where the selection was based on homoscedastic standardized residuals and lowest Bayesian Information Criteria (BIC). Alpha coefficient represented the importance of past innovations (with 1 or 2 lags), while gamma informs about asymmetric behaviour (higher volatility under depreciation), as well as beta refers to the volatility persistence (Tab. 4). Traditionally the volatility persistence has the highest value, so the result at GMD/USD is quite exceptional.

Table 4: GARCH Model Parameters (Currencies in USD Denomination)

\begin{tabular}{|c|c|c|c|c|c|c|c|c|c|}
\hline currency & model & constant & $\alpha_{1}$ & $\alpha_{2}$ & $\gamma$ & $\beta_{1}$ & $\beta_{2}$ & $\delta$ & $\mathrm{BIC}$ \\
\hline KES & TARCH $(1,1,2)$ & 0,00 & 0,23 & & 0,04 & 0,44 & 0,32 & & $-4,20$ \\
\hline GHS & $\operatorname{GARCH}(1,2)$ & 0,00 & 0,11 & & & 0,37 & 0,51 & & $-3,69$ \\
\hline ZAR & GJR GARCH $(1,1,1)$ & 0,00 & 0,02 & & 0,10 & 0,93 & & & $-3,21$ \\
\hline TZS & $\operatorname{GARCH}(1,1)$ & 0,00 & 0,20 & & & 0,80 & & & $-3,92$ \\
\hline UGX & GARCH $(1,1)$ & 0,00 & 0,19 & & & 0,81 & & & $-3,83$ \\
\hline $\mathrm{XAF}$ & GARCH $(1,2)$ & 0,00 & 0,06 & & & 0,20 & 0,91 & & $-3,62$ \\
\hline GMD & TARCH $(2,1,1)$ & 0,00 & 0,14 & 0,28 & 0,17 & 0,49 & & & $-2,83$ \\
\hline MGA & APARCH $(1,1,1)$ & 0,00 & 0,02 & & 0,06 & 0,95 & & 3,44 & $-3,23$ \\
\hline MZN & GJR GARCH $(1,1,2)$ & 0,00 & 0,14 & & 0,12 & 0,29 & 0,51 & & $-3,32$ \\
\hline EUR & $\operatorname{GARCH}(1,1)$ & 0,00 & 0,04 & & & 0,96 & & & $-3,71$ \\
\hline
\end{tabular}

Source: authors' calculations, UCSD toolbox

The Hodrick-Prescott (H-P) filtered $(\lambda=10000)$ dynamic conditional correlation between euro and regional currencies proved to be strong only for XAF due to the pegged regime (Fig. 3). Other African floating currencies were uncorrelated, only the South African Rand (ZAR) showed some weak common movement. The H-P filter was applied to smooth the dataset, following Stavárek (2009).

Figure 3: Dynamic Conditional Correlations between Selected Currencies and EUR/USD between 2000 and 2015 (H-P filtered, $\lambda=10000$ )

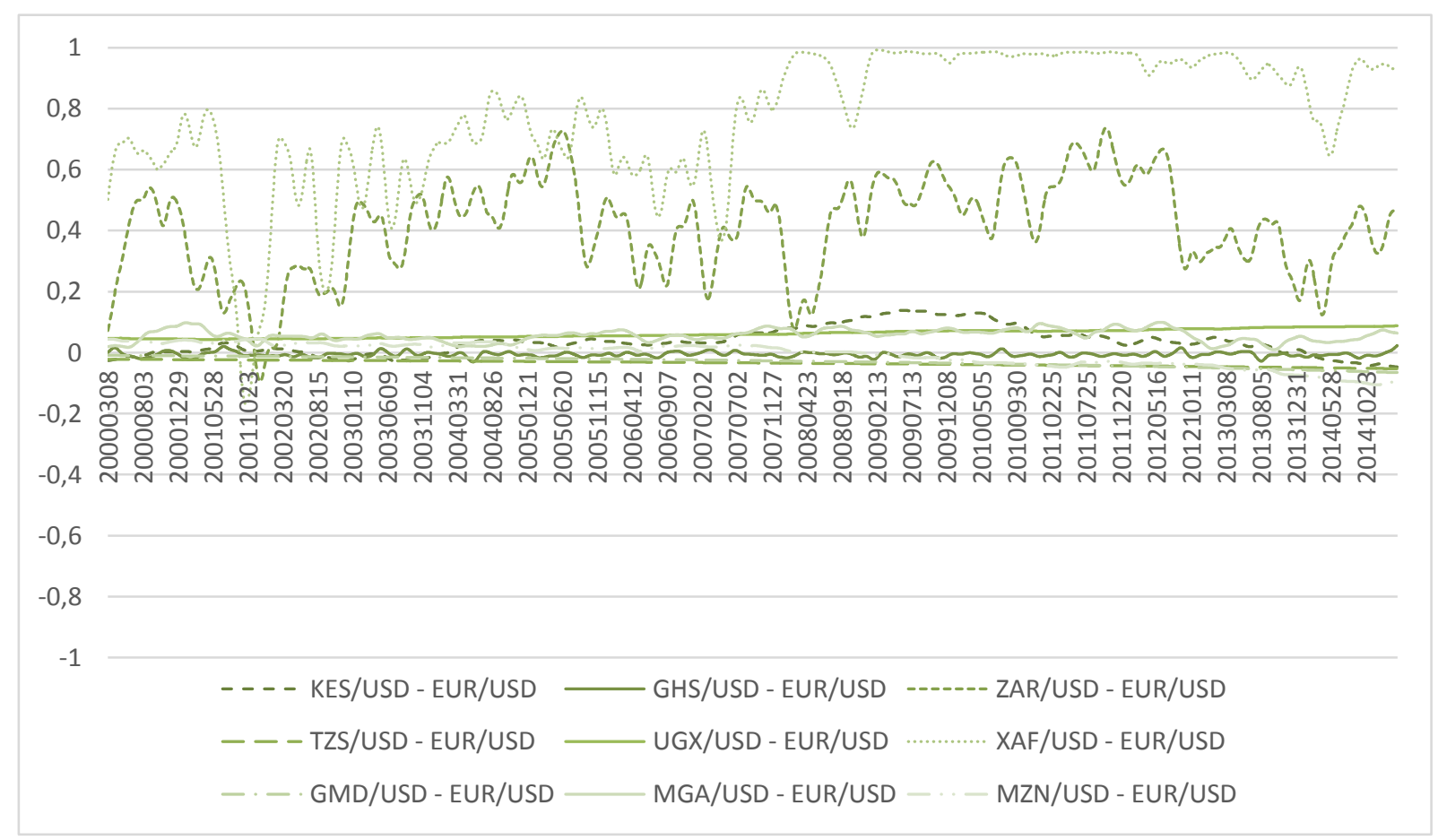

Source: authors' calculations, UCSD toolbox 
These results suggest weaker dependence, compared to the historically strong relations of Central-Eastern European currencies to euro Stavarek (2010) or Babetskaia-Kukharchuk et al. (2008). Therefore we can say that long-term correlation was not affected by business cycles in key economies (or by monetary responses on these developments). These results on Table 5 are suggesting that contagious processes can be checked only in South African and XAF currencies.

Table 5: Average Dynamic Conditional Correlation (Currencies in USD Denomination)

\begin{tabular}{|c|c|c|c|c|c|c|c|c|c|c|c|}
\hline & period & KES & GHS & ZAR & TZS & UGX & $\mathrm{XAF}$ & GMD & MGA & MZN & recession \\
\hline & March 2000 - February 2001 & $-0,01$ & $-0,01$ & 0,21 & 0,03 & 0,05 & 0,54 & $-0,01$ & 0,05 & 0,03 & \\
\hline & March 2001 - October 2001 & $-0,02$ & 0,00 & 0,39 & $\mathbf{0 , 0 3}$ & 0,05 & 0,57 & $-0,01$ & 0,05 & $\mathbf{0 , 0 2}$ & $"+"$ \\
\hline & $\begin{array}{l}\text { November } 2001 \text { - November } \\
2007\end{array}$ & 0,05 & $-0,01$ & 0,44 & 0,03 & 0,06 & 0,76 & $-0,02$ & 0,06 & 0,01 & \\
\hline & December 2007 - May 2009 & $\mathbf{0 , 1 0}$ & $-0,01$ & $\mathbf{0 , 5 1}$ & $\mathbf{0 , 0 4}$ & $\mathbf{0 , 0 7}$ & 0,98 & $-0,04$ & 0,08 & $-0,03$ & "+" \\
\hline US & June 2009 - February 2015 & 0,02 & $-0,01$ & 0,44 & 0,05 & 0,08 & 0,93 & $-0,05$ & 0,05 & $-0,06$ & \\
\hline & March 2000 - December 2007 & 0,04 & $-0,01$ & 0,41 & 0,03 & 0,06 & 0,72 & $-0,02$ & 0,05 & 0,02 & \\
\hline & January 2008 - March 2009 & $\mathbf{0 , 1 0}$ & $-0,01$ & 0,50 & 0,04 & $\mathbf{0 , 0 7}$ & 0,98 & $-0,04$ & $\mathbf{0 , 0 7}$ & $-0,03 \mid$ & $"+"$ \\
\hline & April 2009 - June 2011 & 0,04 & $-0,01$ & 0,53 & 0,04 & 0,07 & 0,97 & $-0,05$ & 0,07 & $-0,04$ & \\
\hline EU|. & July 2011 - March 2015 & $-0,01$ & $-0,01$ & 0,34 & 0,05 & 0,08 & $\mathbf{0 , 8 8}$ & $-0,06$ & $\mathbf{0 , 0 4}$ & $-0,08$ & "+" \\
\hline
\end{tabular}

Source: authors' calculations, UCSD toolbox

Short-term currency market developments were captured in several cases when extreme and normal subsets of dynamic conditional correlations (DCCs) were compared with two-sided ttests to capture contagions, divergences or interdependence (Tab. 6). South African Rand (ZAR) and the EUR-pegged XAF had lost their strong common movement under turbulent times, presenting a divergence - and a vulnerability of the monetary framework.

Table 6: Difference between Highest Dynamic Conditional Correlations

\begin{tabular}{|l|r|r|}
\hline & ZAR/USD-EUR/USD & XAF/USD-EUR/USD \\
\hline avg. correlation(n)-avg. correlation( $(\mathrm{x}+)$ & $-0,04 * *$ & $-0,02 * *$ \\
\hline avg. correlation(n)-avg. correlation( $\mathrm{x}-\mathrm{n}$ & $-0,03 * *$ & 0,00 \\
\hline
\end{tabular}

Notes: *: contagion, **: divergence

Source: authors' calculations, UCSD toolbox

The short-term volatility spillover was been studied with VAR models (Fig. 4) on the vectors of volatility series to see, how daily conditional standard deviations are related to each other. Some currencies seemed to be isolated from other's volatility, like KES, GHS, MGA while others like ZAR, UGX, GMD interfered with another sub-Saharan currencies. Only TZS, XAF, MZN presented significant beta coefficients for EUR - for XAF this behaviour was supported by its EUR-peg. 
Figure 4: Vector Autoregressions on Conditional Standard Deviations (currencies in USD denomination)

$$
\begin{aligned}
& h_{t, K E S}=0.6960 h_{t-1, K E S}+0.3292 h_{t-2, K E S}-0.0671 h_{t-4, K E S}, \mathrm{R}^{2}=0.88, \text { lag no. }=4 \\
& h_{t, G H S}=0.7138 h_{t-1, G H S}+0.3625 h_{t-2, G H S}-0.0942 h_{t-3, G H S}, \mathrm{R}^{2}=0.96, \text { lag no. }=3 \\
& h_{t, Z A R}=0.0173 h_{t-1, K E S}+0.9749 h_{t-1, Z A R}+0.0740 h_{t-1, T Z S}, \mathrm{R}^{2}=0.97, \text { lag no. }=1 \\
& h_{t, T Z S}= \\
& 0.0511 h_{t-1, K E S}+1.1349 h_{t-1, T Z S}-0.2024 h_{t-2, T Z S}+0.2809 h_{t-1, E U R}-0.2340 h_{t-2, E U R}+ \\
& 0.0002, \mathrm{R}^{2}=091, \text { lag no. }=2 \\
& h_{t, U G X}=0.0300 h_{t-2, G H S}+1.046 h_{t-1, U G X}-0.1208 h_{t-2, U G X}+0.0002, \mathrm{R}^{2}=0.89, \text { lag no. }=2 \\
& h_{t, X A F}= \\
& -0.0129 h_{t-2, K E S}+0.0097 h_{t-1, T Z S}+0.1571 h_{t-1, X A F}+0.9050 h_{t-2, X A F}-0.0965 h_{t-3, X A F}+ \\
& 0.0203 h_{t-1, M G A}-0.0215 h_{t-2, M G A}+0.0089 h_{t-2, M Z N}-0.0113 h_{t-3, M Z N}-0.1847 h_{t-1, E U R}+ \\
& 0.2000 h_{t-2, E U R}+0.000, \mathrm{R}^{2}=0.96, \text { lag no. }=3 \\
& h_{t, G M D}= \\
& 0.7513 h_{t-2, K E S}-0.2829 h_{t-3, K E S}-0.3571 h_{t-4, K E S}+1.2662 h_{t-1, G M D}-0.7455 h_{t-2, G M D}+ \\
& 0.3740 h_{t-3, G M D}-0.1463 h_{t-4, G M D}+0.0634 h_{t-4, G M D}+0.0022, \mathrm{R}^{2}=0.76, \text { lag no. }=5 \\
& h_{t, M G A}=1.064 h_{t-1, M G A}-0.0606 h_{t-3, M G A}, \mathrm{R}^{2}=0.98, \text { lag no. }=3 \\
& h_{t, M Z N}= \\
& 0.7137 h_{t-1, M Z N}+0.3675 h_{t-2, M Z N}-0.0518 h_{t-3, M Z N}+0.0477 h_{t-4, M Z N}-0.1143 h_{t-5, M Z N}+ \\
& 0.7086 h_{t-1, E U R}-1.1576 h_{t-2, E U R}+0.0005, \mathrm{R}^{2}=0.93, \text { lag no. }=5 \\
& h_{t, E U R}=0.003 h_{t-1, K E S}+0.002 h_{t-1, T Z S}+0.003 h_{t-1, U G X}+0.012 h_{t-1, X A F}+0.9812 h_{t-1, E U R}, \\
& \mathrm{R}^{2}=0.99, \text { lag no. }=1
\end{aligned}
$$

Source: authors' calculations, JPL toolbox

The African floating currencies presented some special features in their short-term dynamics: most of them were uncorrelated with EUR/USD rate despite the strong trade and political ties but monetary easing after 2008 decreased the occurrence of extreme currency fluctuations. The short-term volatility spillover supported the idea of market isolation, because currency volatility was affected only by its own past values.

\section{Conclusion}

Current article evaluated the FX exposure of the African countries with floating exchange rate regimes to compare them with the pegged alternative, like XAF. The analysed countries have many bounds to the developed countries: among ordinary trade relations, their integration into the world economy is promoted via preferential tariff agreements, aid and discounted credit programs. The economic actors in the sample countries had to pay the price of floating regimes as the results about the fat-tailed extreme fluctuations and volatility models suggested, but their currencies were uncorrelated with euro and mostly isolated from its volatility as well. Therefore contagions were not able to emerge on these markets despite the real, political and financial links among these countries and the Eurozone or US market, but the flexibility of the FX regimes allowed the depreciation against euro to maintain pricecompetitiveness. It means that international and national development and aid programs shall not focus on the problem at the sample currencies that they would be biased by changes international market-mood - until these currencies are not attractive enough to step on the menu of international investors. After a currency enters to the "emerging" status like CEE or 
South African foreign exchanges, their movements will be influenced by international portfolio re-balancing decisions.

\section{References}

[1] BABETSKAIA-KUKHARCHUK, O., I. BABETSKI and J. PODPIERA, 2008. Convergence in exchange rates: market's view on CE-4 joining EMU. Applied Economics Letters, 15, 385-390. ISSN 1466-4291.

[2] BEARCE, D., 2002. Monetary Divergence: Domestic Policy Autonomy in the PostBretton Woods Era. Ann Arbor: University of Michigan Press. ISBN 978-0-472-06961-3

[3] BEKAERT, G., C. R. HARVEY and A. NG, 2005. Market Integration and Contagion. Journal of Business, 78(1), 39-69. ISSN 0021-9398.

[4] BUBÁK, V., E. KOCENDA and F. ZIKES, 2011. Volatility transmission in emerging European foreign exchange markets. Journal of Banking \& Finance, 35(2011), 28292841. ISSN 0378-4266.

[5] CADF, 2013. Brochure of CADFund. Beijing: China-Africa Development Fund.

[6] CAMPBELL, R., K. KOEDIJ and P. KOFMAN, 2002. Increased Correlation in Bear Markets. Financial Analysts Journal, 58(1), 87-94. ISSN 0015-198X.

[7] CAPPEIELLO, L., R. F. ENGLE and K. SHEPPARD, 2006. Asymmetric Dynamics in the Correlations of Global Equity and Bond Returns. Journal of Financial Econometrics, 4, 537-572. ISSN 0304-405X.

[8] CLAUSET, A., C. R. SHALIZI and M. E. J. NEWMAN, 2009. Power-law distributions in empirical data. SIAM Review, 51(4), 661-703. ISSN 1095-7200.

[9] COLLINS, D. and N. BIEKPE, 2003. Contagion: a fear for African equity markets? Journal of Economics and Business, 55, 285-297. ISSN 0148-6195.

[10] DASH, P., 2014. India-Africa Trade: Current Trends and Policy. Journal of Studies in Dynamics and Change, 1(7), 268-279. ISSN 2348-7038.

[11] DE BOCK, R. and I. DE CARVALHO FILHO, 2015. The behavior of currencies during risk-off episodes. Journal of International Money and Finance, 53, 218-234. ISSN 10424431.

[12] ENGLE, R. F., 2002. Dynamic Conditional Correlation - A Simple Class of Multivariate GARCH Models. Journal of Business and Economic Statistics, 20(3), 377-389. ISSN 1537-2707.

[13] FARKAS, B., 2011. The Central and Eastern European model of capitalism. PostCommunist Economies, 23(1), 15-34. ISSN 1465-3958.

[14] FORBES, J. K. and R. RIGOBON, 2002. No contagion, only interdependence: measuring stock market comovements. Journal of Finance, 57(6), 2223-2261. ISSN 1540-6261.

[15] GABAIX X., P. GOPIKRISHNAN, V. PLEROU and H. E. STANLEY, 2003. A theory of power-law distributions in financial market fluctuations. Nature, 423, 267-27. ISSN 0028-0836.

[16] GÁSPÁR A. and B. UDVARI, 2011. A Loméi Egyezmények felzárkózásra gyakorolt hatása. Statisztikai Szemle, 4, 420-447. ISSN 0039-0690. 
[17] HERYÁN, T., I. PALEČKOVÁ and N. RADIĆ, 2015. Comparison of monetary policy effects on lending channel in EMU and non-EMU countries: Evidence from period 19992012. Working Paper in Interdisciplinary Economics and Business Research, 3. Karviná: Silesian University in Opava, School of Business Administration in Karviná.

[18] IMF, 2009. BoP Manual. 6th ed. Washington D. C.: International Monetary Fund. ISBN 978-1-58906-812-4.

[19] IMF, 2013. IMF Annual Report on Exchange Arrangements and Exchange Restrictions. Washington D. C.: International Monetary Fund. ISBN 978-1-49832-332-1.

[20] KESKINA, M., B. DEVIRENB and Y. KOCAKAPLAN, 2011. Topology of the correlation networks among major currencies using hierarchical structure methods. Physica A, 390, 719-730. ISSN 0378-4371.

[21] LÜTKEPOHL, H. and M. KRATZIG, 2004. Applied Time Series Econometrics. Cambridge: Cambridge University Press. ISBN 978-0-521-547-871.

[22] MCCOSKEY, S. K., 2002. Convergence in Sub-Saharan Africa: a nonstationary panel data approach. Applied Economics, 34(7), 819-829. ISSN 1466-4283.

[23] MORALES, L. and B. ANDREOSSO-O'CALLAGHAN, 2014. The global financial crisis: World market or regional contagion effects? International Review of Economics and Finance, 29, 108-31. ISSN 1059-0560.

[24] NAUDÉ, W. A., 2004. The effects of policy, institutions and geography on economic growth in Africa: an econometric study based on cross-section and panel data. Journal of International Development, 16(6), 821-849. ISSN 1099-1328.

[25] PRITSKER, M., 2001. The channels for financial contagion. In: S. CLAESSENS and K. FORBES, eds. International Financial Contagion. Dordrecht: Kluwer Academic Publishers. ISBN 978-1-4757-3314-3.

[26] SIRIWARDANA, M. and B. DOLLERY, 2002. The Impact of the Asian Economic Crisis on Southern African Economies. African Development Review, 14(2), 276-297. ISSN 1467-8268.

[27] STAVÁREK, D., 2009. Assessment of the Exchange Rate Convergence in EuroCandidate Countries. Amfiteatru Economic Journal, 11(25), 159-180. ISSN 1582-9146.

[28] STAVÁREK, D., 2010. Exchange rate volatility and the asymmetric fluctuation band on the way to the Eurozone. Applied Economics Letters, 17(1), 81-86. ISSN 1466-4291.

[29] UDVARI, B., 2008. A Loméi Egyezmények gazdasági hatásai Fekete-Afrikában. KülVilág, 3-4, 39-60. ISSN 1785-5284.

[30] UDVARI, B., 2011. Az Aid for Trade megjelenése az Európai Unió fejlesztési politikájában. Fordulat, 4, 96-122. ISSN 15850560.

[31] UDVARI, B., 2012: Az EU és a fejlődő országok kapcsolata: Az Aid for Trade szerepe. Köz-Gazdaság, 4, 95-110. ISSN 1788-0696.

[32] UDVARI, B., 2014. Impacts of Aid for Trade on Trade with the EU The Role of Old and New Member States. Journal of Global Policy and Governance, 3(1), 77-93. ISSN 21947759.

[33] WILLIAMS, B. R., 2015. African Growth and Opportunity Act (AGOA): Background and Reauthorization. Washington D. C.: CRS Report, Congressional Research Service. 